\title{
Alfredo dos Santos Oliva. A história do diabo no Brasil
}

Antonio Paulo Benatte*

São Paulo: Fonte Editorial, 2007. 285p.

Em suas célebres teses Sobre o conceito de História, Walter Benjamin referiu-se à teologia como "reconhecidamente pequena e feia", um saber que "não ousa mostrar-se". A julgar por trabalhos recentes como A história do diabo no Brasil, do historiador e teólogo Alfredo dos Santos Oliva, esse complexo de inferioridade parece ser coisa do passado, pois é justamente o 'mostrarse' da teologia que faz a diferença na análise historiográfica aqui levada a efeito.

Já na introdução, o autor deixa ver o lugar existencial e epistemológico de onde fala, no que concerne tanto à sua identidade religiosa — pentecostal - quanto às suas opções teóricas e metodológicas, ancoradas na tradição francesa da historiografia de Bloch e Febvre a Michel Foucault. Oliva não esconde sua pertença religiosa nem faz dela uma bandeira, mas busca objetivála o máximo possível. A confessionalidade confessada não impede a objetivação; antes, é a sua condição necessária. Da tensão entre racionalismo e crença o autor não faz um dilema; sua posição é decididamente laica: “O historiador da religião deve estar preocupado em produzir conhecimento academicamente rigoroso e não subsídios para uma apologia, seja ela secular ou religiosa" (p.21). Apesar disso, não cai no racionalismo míope, tão comum nesse tipo de pesquisa; pelo contrário, adota uma perspectiva de 'razão sensível' que poderíamos chamar pós-moderna, não fosse o rótulo ter-se desgastado a ponto de nada mais dizer. Ao discutir a obra seminal de Michel de Certeau, afirma Oliva que "a historiografia é uma forma de conhecimento e escrita que se situa entre a ficção e a realidade e em algum ponto entre a subjetividade e a objetividade" (p.18). Esse difícil equilíbrio, mantido ao longo de todo o texto, faz que o livro seja uma contribuição não apenas conteudística como também metodológica para a historiografia da religião no Brasil contemporâneo. O último capítulo, estritamente metodológico, reafirma essa relevância.

\footnotetext{
${ }^{\star}$ Depto. de História da Universidade Estadual de Campinas (Unicamp) - Bolsista da Fapesp. Rua Adriático, 151, bl. 14, ap. 52, Jd. do Estádio. 09172-180 Santo André - SP - Brasil. apbenatti@ibest.com.br.
} 
O tema do livro é bem delimitado no tempo e no espaço: as práticas discursivas sobre o diabo na Igreja Universal do Reino de Deus (IURD), de 1977 (ano de fundação da igreja do bispo Macedo) até 2005, ano de defesa da tese de que resultou o livro. Trata-se, pois, das práticas e representações em torno do mal na principal denominação do assim chamado neopentecostalismo brasileiro; mas, por tratar-se do diabo, "esse personagem já bastante idoso", o autor, para fundamentar suas análises em terreno seguro, sente-se obrigado a traçar, em linhas gerais, uma história do diabo na longa duração, do judaísmo antigo e do cristianismo primitivo aos dias atuais. Essa excursão poderia ser considerada um desvio de rota, mas, além de mostrar as continuidades e descontinuidades nas representações do "Inimigo de Deus e de nossas almas", ela fundamenta a análise mais circunscrita que se segue; pois, obviamente, as práticas e crenças da IURD sobre o vil tentador não partem de um vácuo nem são uma construção ex nihil, e sim retomam criativamente representações historicamente construídas desde os tempos bíblicos. Ou seja, as fontes primeiras das práticas e das representações contemporâneas em torno do Adversário são os textos bíblicos canônicos do Novo e do Antigo Testamento; daí as visões vetero e neotestamentárias do mal — ou melhor, de sua personificação no diabo e em seus demônios - serem um ponto de partida (ou de chegada) necessário. As pesquisas sobre a história do diabo na cultura ocidental permitem mostrar, por exemplo, como as práticas acerca desse personagem na IURD (o discurso demonizante, os rituais de exorcismo) não se separam do amplo processo de demonização da alteridade, e em especial da alteridade religiosa, que atravessa a história do cristianismo desde a Igreja primitiva.

A seguir, o historiador-teólogo aborda a implantação e a difusão do pentecostalismo no Brasil desde o começo do século XX. A partir de suas raízes no metodismo, no avivalismo e nos movimentos de santidade, contextualiza o pentecostalismo como uma religião atrelada às camadas populares urbanas, mostrando como "dentro desta categoria social [ele] viria a ser uma importante alternativa de reconstrução de um mundo que se dissolvia rapidamente" (p.123). Atento às diversas continuidades e rupturas na constituição do campo, o autor percebe uma série de diferenciações aparentemente insignificantes que atravessam e constituem o(s) pentecostalismo(s). Aqui, Oliva, mesmo endossando teses consagradas sobre esse movimento sócio-religioso no Brasil, distancia-se criticamente das tipologias ou classificações prévias construídas pelas ciências sociais, inclusive a história; para isso, adota uma perspectiva mais compreensiva (hermenêutica) e menos explicativa do fenômeno religioso. 
Para efeitos comparativos, o autor analisa a seguir a visão do mal, do pecado e do diabo em várias perspectivas: no protestantismo tradicional, na teologia da libertação e no pentecostalismo clássico, até desembocar no neopentecostalismo da IURD como expressão de uma religiosidade integrada à lógica sistêmica do capitalismo tardio. Dificilmente esse empreendimento poderia ser realizado sem erudição e desenvoltura teológicas. Assim, para a nova história religiosa, parece claro que, especialmente no caso das grandes "religiões do livro", a abordagem multidisciplinar do fenômeno religioso não possa mais excluir a teologia: o conhecimento teológico mostra-se insubstituível como chave para códigos religiosos que de outro modo passariam imperceptíveis por não se deixarem reduzir ao logos de qualquer ciência.

Mas a principal virtude do livro está em que, sem abdicar de uma postura crítica, o autor adota uma atitude empática do fenômeno religioso, muito distante das posturas científicas que, do alto do tribunal do santo ofício do saber, arvoram-se no direito de julgar e condenar, sem apelação, visões de mundo distantes de suas verdades pretensamente iluminadas e supostamente libertárias. A essa postura judicativa o historiador-teólogo contrapõe uma perspectiva 'relativista', como quando se opõe à interpretação, inspirada em Lévy-Bruhl, do diabólico na IURD como manifestação de uma 'mentalidade primitiva' ou 'pré-lógica'.

No Brasil, os estudos da religião - tradicionais nas ciências sociais desde Nina Rodrigues, passando por Roger Bastide e Duglas Teixeira Monteiro, entre muitos outros - têm crescido quantitativa e qualitativamente nas últimas décadas; e não é diferente com a história: o chamado cultural turn, ou o diálogo com a antropologia, tem favorecido a renovação da história religiosa. O livro de Oliva, em diálogo com a produção de ponta nessa área, insere-se num conjunto de estudos em que a religiosidade aparece intimamente articulada à cultura, no sentido antropológico do termo. Com efeito, os complexos liames entre religião e cultura perpassam toda a obra. O exorcismo, por exemplo, é analisado como um rito de passagem que, demonizando o outro, "constrói o sentido de pertença à igreja" (p.145).

Em alguns momentos, dada a amplitude do tema - a longa história do diabo - , parece haver um abuso de material bibliográfico; mas, na maior parte do tempo - e especialmente no terceiro capítulo, onde investiga como a IURD compreende e fundamenta teologicamente sua demonologia - , prevalece o tratamento empírico do objeto mais circunscrito, quando então a abordagem qualitativa, propiciada pela observação participante, é comple- 
mentada pela análise de fontes primárias: o material impresso pela IURD, de teor teológico e devocional.

Em suma, trata-se de uma contribuição importante para as linhas de pesquisa preocupadas em compreender as múltiplas dimensões da religiosidade popular brasileira, especialmente quanto aos crentes chamados pentecostais e neopentecostais. Mas o trabalho permite também reflexões mais gerais. Situando-se na confluência da história religiosa e da história cultural, o livro permite ver que, assim como as tentativas de "matar Deus", as tentativas de "assassinar o Diabo" também fracassaram: a persistência da crença na existência do Inimigo sobreviveu à secularização, à racionalização e ao desencantamento do mundo que, segundo as clássicas teses weberianas, caracterizariam a modernidade ocidental. Não é difícil observar que a crença religiosa, muito mais que a racionalidade strictu sensu, continua a ser a dinamis da maioria das práticas culturais. Permanece a certeza de que, sem compreendermos os fenômenos religiosos não compreenderemos as grandes mutações sociais e culturais de nosso tempo. A renitente permanência das crenças religiosas num corpo social crescentemente secularizado exigirá, queiramos ou não, um diálogo entre os adeptos das visões científicas e os das visões religiosas de mundo.

Nesse sentido, a autor, firmando-se em teorias de Jüergen Habermas, conclui seu livro afirmando a necessidade de um diálogo entre ciência e religião. Se, como dizia Kierkegaard, a fé começa onde termina a razão, pode-se imaginar a dificuldade inerente a essas conversações; dificuldade exacerbada, de um lado, pelos fundamentalismos, e, de outro, pelos virulentos ataques do cientificismo ateu, ou "ateísmo científico". Com efeito, reduzir a religião à satisfação de interesses materiais ou mesmo psíquicos — como ainda faz a ciência de corte iluminista e positivista - é pouco entender de religião. A teologia, é claro, não deixa de ser uma ciência (um logos); mas, de qualquer modo, é um discurso menos reducionista e mais aberto à compreensão das necessidades espirituais da humanidade. Por isso, e cada vez mais, o saber teológico é chamado a ocupar uma função mediadora nesse importante diálogo.

Resenha recebida em janeiro de 2008. Aprovada em abril de 2008. 